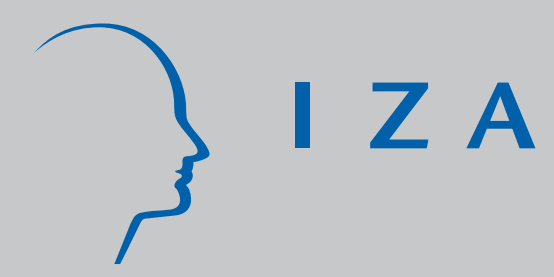

IZA DP No. 4048

How Does Household Production Affect

Measured Income Inequality?

Harley Frazis

J ay Stewart

February 2009 


\title{
How Does Household Production Affect Measured Income Inequality?
}

\author{
Harley Frazis \\ U.S. Bureau of Labor Statistics \\ Jay Stewart \\ U.S. Bureau of Labor Statistics \\ and IZA
}

Discussion Paper No. 4048
February 2009

IZA
P.O. Box 7240
53072 Bonn
Germany

Phone: +49-228-3894-0

Fax: +49-228-3894-180

E-mail: iza@iza.org

\begin{abstract}
Any opinions expressed here are those of the author(s) and not those of IZA. Research published in this series may include views on policy, but the institute itself takes no institutional policy positions.

The Institute for the Study of Labor (IZA) in Bonn is a local and virtual international research center and a place of communication between science, politics and business. IZA is an independent nonprofit organization supported by Deutsche Post Foundation. The center is associated with the University of Bonn and offers a stimulating research environment through its international network, workshops and conferences, data service, project support, research visits and doctoral program. IZA engages in (i) original and internationally competitive research in all fields of labor economics, (ii) development of policy concepts, and (iii) dissemination of research results and concepts to the interested public.
\end{abstract}

IZA Discussion Papers often represent preliminary work and are circulated to encourage discussion. Citation of such a paper should account for its provisional character. A revised version may be available directly from the author. 


\section{ABSTRACT \\ How Does Household Production Affect Measured Income Inequality?*}

Although income inequality has been studied extensively, relatively little attention has been paid to the role of household production. Economic theory predicts that households with less money income will produce more goods at home. Thus extended income, which includes the value of household production, should be more equally distributed than money income. Previous studies have found this to be the case and have speculated that the more-equal distribution of extended income is due to the weak correlation between money income and household production income. We also find that extended income is more equally distributed than money income. The main contribution of our paper is that we identify the reason for this result. Our sensitivity analysis indicates that virtually all of the decline in measured inequality when moving from money income to extended income is due to the addition of a large constant - the average value of household production - to money income and that measured inequality is insensitive to the correlation between money and household production income. The practical importance of this result is that estimates of extended income inequality are robust to imputation procedures and that researchers can obtain accurate estimates of trends by simply using mean values of household production income.

JEL Classification: D31, J22, D63

Keywords: inequality, household production

Corresponding author:

Jay Stewart

U.S. Bureau of Labor Statistics

2 Massachusetts Avenue, NE

Washington, DC 20212

USA

E-mail: stewart.jay@bls.gov

\footnotetext{
* The authors thank Peter Gottschalk, Jim Spletzer, Frank Stafford, and participants in sessions at the 2004 meetings of the International Association of Research on Income and Wealth, the 2005 Allied Social Science Associations meetings, and the Levy Economics Institute conference "Time Use and Economic Well-Being." We also thank two anonymous referees for their helpful comments. The views expressed here are those of the authors and do not necessarily reflect the views of the U.S. Department of Labor or the Bureau of Labor Statistics.
} 


\section{Introduction}

Inequality of earnings and inequality of household income have increased over recent decades, both in the United States and to a lesser extent in other industrialized countries (see Gottschalk and Smeeding 1997 for a review). In response to these developments, an outpouring of research has described and tried to explain these trends. Most of these studies concern inequality in money income, where data are more readily available. But, money income is not a complete measure of economic welfare. ${ }^{1}$

Another branch of the inequality literature has incorporated the value of household production--goods and services produced at home--into measures of income to arrive at what is referred to as "extended income." This measure is sensible, because home production represents additional "income" that is available for consumption but is not included in money income. Household production models (for example, Gronau 1986) predict that high-wage workers will do less nonmarket work than low-wage workers (assuming that all individuals have identical preferences and are equally productive in nonmarket work). This model can easily be generalized to two-person households by assuming that husbands and wives maximize a common utility function. High-wage workers still spend less time in household production activities than low-wage workers, and individuals with high-wage spouses spend less time doing household work than individuals with low-wage spouses. ${ }^{2}$ Therefore we would expect a

\footnotetext{
${ }^{1}$ Other recent studies have attempted to describe inequality along other dimensions--for example, inequality in consumption (Johnson and Shipp 1995, 1997, and 2005; Krueger and Perri 2002) and in total compensation including fringe benefits (Pierce 2001).

${ }^{2}$ For more details, please see the Appendix of the Working Paper version of this paper (available from the authors upon request), which presents the Gronau (1986) model, extends the model to two-person households, and discusses the assumptions that drive these results.
} 
negative correlation between money income and time spent in household production, which implies that extended income will be more equally distributed than money income.

Several studies (Bonke, 1992; Jenkins and O'Leary, 1996; Gottschalk and Mayer, 2002; Bonke, Deding, and Lausten, 2004; and Wolff, Zacharias, and Caner, 2004) have empirically compared inequality measures using extended income and money income, and most have found that extended income is more equally distributed. ${ }^{3}$ Jenkins and O'Leary (1996) argued that the main reason for this result is that "...the amount of domestic work households do--and hence their household production income--appears not to vary much in absolute terms with money income level." However, the data that have been available to examine this question are far from perfect. Jenkins and O'Leary (1996) speculated that the weak relationship between money income and household production income may be due to the procedures used to address data deficiencies--in particular the imputation of household production income--and suggested that a stronger relationship might reverse the sign of the effect of including household production.

The ideal data would include information on both household production and income for the same reference period and for every member of the household. However, time-use surveys, which are the main source of data for household production, typically collect data for only one or two days, and many collect data for only one household member. This results in an incomplete picture of household production at both the individual and household level. ${ }^{4}$ Equally important is the fact that time-use data typically do not have income data and datasets with income

\footnotetext{
${ }^{3}$ The exceptions are Bonke, Deding, and Lausten (2004) and some specifications in Bonke (1992). Note that both use Danish data with markedly smaller money income inequality than the US or UK.

${ }^{4}$ A study by Gottschalk and Mayer (2002) avoided problems with time-use data by using data from Panel Study of Income Dynamics (PSID), which contains information on earned and unearned income as well as a measure of the usual amount of time spent doing household work. The main drawback to this approach, as they acknowledge, is that the PSID measure of household production leaves much to be desired. The question does not define household production, which could result in biased estimates if there are systematic differences in how respondents report.
} 
information have no information on household production. Thus it is necessary to combine these two types of dataset and estimate the value of household production to get a complete picture. ${ }^{5}$

The most common approach is to impute the value of household production income for individuals in the income dataset (Bonke, 1992; Jenkins and O'Leary, 1996; and Wolff, Zacharias, and Caner, 2004). First, the time spent in household production is estimated from time-use data in a regression framework using covariates that are common to both datasets. The predicted values are converted to the same time period as the income variables and then merged into the income dataset using the set of common variables. However, given that most time-use surveys have little or no income data, income generally cannot be used as a covariate in the imputation procedure, which means that any relationship between income and time spent in household production is lost.

The use of predicted values of household production also results in a loss of the variation that is not accounted for by the covariates. To remedy this, the Jenkins and O'Leary study perturbed estimated household production by adding a random term with variance equal to that of the regression residual to the imputed values. A more recent study by Bonke, Deding, and Lausten (2004) multiplied each respondent's average hours per day spent in household production by 365 . These approaches tend to exaggerate measured long-run inequality in household production, because they include day-to-day within-person variation in addition to long-term between-person variation.

Our paper contributes to the literature in two ways. First, we develop improved procedures for addressing the data deficiencies described above. Our dataset, the American respondents overreporting because they believe that they should do a lot of housework (social desirability bias). 
Time Use Survey (ATUS), has information on both time-use and income, which makes it possible to use income as a covariate in the imputation procedure. Rather than using a simple linear regression, our procedure uses a flexible functional form to better capture the relationship between earnings and household production income. We also develop a procedure that allows us to produce a range of estimates based on alternative assumptions about the extent of long-run unobservable heterogeneity in household production and the correlation between the household production of husbands and wives.

Second, and more important, we ascertain why extended income is more equally distributed than money income. We show that virtually all of the decline in measured inequality is due to the addition of the mean value of household production to each household's money income, and that the variability of household production and the correlation between household production and money income contribute very little. Moreover, a given percentage change in the mean value of household production has a much larger effect on measured inequality than does the same relative change in the variability of household production or the correlation between household production and money income. In fact, holding the mean value of household production constant at the estimated value and the variance of household production constant at the maximum value that is consistent with our data, we show that extended income is more equally distributed than money income even if household production and money income are perfectly positively correlated. This contradicts Jenkins and O'Leary's speculation regarding the importance of the relationship between income and household production for signing the effect of including household production.

\footnotetext{
${ }^{5}$ Bonke (1992) was able to use income data from the register of income taxation for the respondents in the time-use survey, but this alternative is usually not available to researchers.
} 
These results are important for researchers who are interested in estimating trends in extended income inequality, because time-use surveys tend to be done infrequently and the covariates available for imputation are not always the same from survey to survey. They imply that researchers can obtain reasonable estimates of extended income inequality using mean values of household production because real changes in unobserved heterogeneity in household production and the relationship between money and household production have little effect. However, they also imply that it is important to correctly estimate the mean value of household production.

\section{Data and Methods}

Our data come from the 2003 ATUS, which is a stratified random sample drawn from households that have completed their participation in the Current Population Survey (CPS) and is representative of the U.S. civilian noninstitutional population. The ATUS interviews one person per household and collects one diary per person. The ATUS collects information on the amount of time spent in over 400 detailed activities. Although it does not collect information on other activities done simultaneously (secondary activities), there are several questions at the end of the time diary that ask respondents to identify times and activities during which children under 13 were in their care (secondary childcare).

The ATUS also contains detailed demographic and labor force information, including employment status, usual hours worked per week, and earnings on the main job. ${ }^{6}$ For the respondent's spouse or unmarried partner, the ATUS collects detailed demographic information 
and basic labor force information--employment status (employed or not employed) and total hours usually worked per week. Earnings are available from the CPS if the spouse was employed at the time of the last CPS interview. The ATUS does not collect any labor force information for other household members.

We divided the sample into single-adult and married-couple households. Our sample of single-adult households includes respondents aged 25-64 who had no spouse or unmarried partner present. Our married-couple sample includes households where both spouses are between 25 and 64. We excluded households with other adult (18+) family members in order to avoid the need to estimate the contribution of the other adult to household production. We also ignore children's contributions to income and household production. Our final sample is 10,048 observations.

Detailed information on earned and unearned income is available for about one-third of ATUS respondents by linking to their March CPS Income Supplement interviews. ${ }^{7}$ Of the 10,048 observations in our sample, 3,329 observations had income data available from the March supplement and 2,639 of these had unallocated earnings. ${ }^{8}$ Family income and non-labor earnings variables for the remaining two-thirds of the sample are predicted by regression using variables common to both the ATUS and the March CPS. We excluded observations with allocated earnings and replaced family incomes below the $1^{\text {st }}$ percentile with the $1^{\text {st }}$ percentile value.

\footnotetext{
${ }^{6}$ The earnings data are carried over from the final CPS interview. The earnings questions are asked in ATUS if the respondent had a new job in ATUS (either changed jobs or made a nonemployment-to-employment transition) or earnings were allocated in the last CPS interview.

${ }^{7}$ Households are in the CPS for 4 consecutive months, out for 8, then back in for 4 . Because of the sample rotation scheme used in CPS, only about one-third of ATUS respondents--those whose final CPS interviews were in MarchJune--were interviewed in March. There is a lag between the final CPS interview and introduction into the ATUS, so that most of the ATUS respondents who were matched to March were interviewed for ATUS in June through September.
} 
Households where other (minor) family members contributed more than 10 percent of income were also excluded.

As in previous studies, we classify activities as household production using the "thirdperson" criterion (Reid, 1934). We used two alternative definitions of nonmarket work. The first definition includes household activities (including purchasing goods and services) and care of household members done as a primary activity. ${ }^{9}$ The second definition adds childcare done as a secondary activity. To avoid double counting in the second definition, we excluded secondary childcare that was done at times when the respondent was engaged in household production as a primary activity.

We use the replacement-cost approach to value household production, whereby time spent in household production is valued at the cost it would take to purchase the production in the market. We considered using other approaches to valuing household production. The opportunity-cost approach, which values time spent in household production at the individual's market wage, has some conceptual and practical difficulties associated with it. Conceptually, the implicit assumption that hours of paid work are freely variable at the margin may not hold; workers, at least in the short run, may have no choice in their working hours. Perhaps more importantly, the opportunity cost approach assumes that people who are highly productive in market work are just as productive doing household work. It is hard to imagine that a lawyer is five times more productive building a deck than a carpenter. On a practical level, it would be

\footnotetext{
${ }^{8}$ Respondents frequently do not respond to the income questions in the CPS. In these cases the Census Bureau imputes the income variables using a hot-deck procedure, where recipient observations receive data from donor observations with the same demographic characteristics.

${ }^{9}$ We exclude volunteer work and care of non-household members from all of our measures. These activities could legitimately be classified as nonmarket work, but they do not contribute directly to the household's income. In any case, the time spent in these activities is small, and their inclusion would have no effect on our results.
} 
necessary to impute a wage for nonworkers. ${ }^{10}$ Another approach was used by Gronau (1980), who specified a functional form for the marginal product of nonmarket work, estimated its parameters using time-diary data, and integrated the function for each individual in the sample. This approach has the advantage of being grounded in theory, but it is sensitive to functional form.

To implement the replacement-cost approach we use either a specialist wage that corresponds to purchasing the specific activity or a generalist wage. The specialist wages were generated using the Outgoing Rotation Group files from the CPS as follows. We computed the hours-weighted mean wage for each 3-digit occupation. ${ }^{11}$ The time spent in each nonmarket activity was valued at the wage for the occupation that most closely resembles the activity. ${ }^{12}$ For the generalist wage, we used the average wage for Maids and Housekeepers. We made no adjustments to account for differences in productivity in household production across individuals, although the lower productivity of non-specialists is a primary justification for using a generalist wage. ${ }^{13}$

Because, as noted above, the ATUS interviews only one person per household and collects only one diary per person, we have an incomplete picture of household production--the best we can do is to estimate means of household production conditional on observable characteristics. We use a variation of the regression methods used in the Bonke (1992) and Jenkins and O’Leary (1996) studies to predict household production. We regress the

\footnotetext{
${ }^{10}$ Bonke, Deding, and Lausten (2004) and some specifications of Bonke (1992) use the opportunity cost method, which is one reason for their finding of greater inequality of extended income relative to money income.

${ }^{11}$ An hours-weighted mean weights individuals with earnings in part-time jobs less heavily. Letting E denote weekly earnings, $\mathrm{H}$ denote weekly hours, and $\mathrm{W}$ denote the person weight; the hours-weighted mean is calculated as: $\sum W_{i} E_{i} / \sum W_{i} H_{i}$, whereas the person-weighted mean is calculated as: $\sum W_{i}\left(E_{i} / H_{i}\right) / \sum W_{i}$.

${ }^{12}$ This crosswalk is available from the authors upon request.
} 
equivalence-scale normalized value of household production on the log of annual family income, the log of weekly earnings, the log of non-labor income, the log of the hourly wage, dummies for employment status ( 2 categories), education level (4 categories), age, and the number of children zero to 5,6 to 12 , and 13 to 17 . We run separate regressions by marital status and sex. For married respondents, we also include the log of spouse's weekly earnings, log of the spouse's wage, and dummies for spouse's employment status, education level, and age.

Because of the importance of capturing the relationship between household production and income, we use a flexible specification for the log of family income. Specifically, we use Gallant's (1981) Fourier series expansion. Transforming the log of family income into the variable $Z \in(0,2 \pi)$ and letting $X$ denote the vector of regressors listed above, our Fourier specification is:

$$
f(Z, X)=a+b Z+c Z^{2}+\sum_{j=1}^{J}\left(\beta_{1 j} \cos (j Z)+\beta_{2 j} \sin (j Z)\right)+X \beta
$$

A function's Fourier expansion has the desirable property that the differences between the true value of a function $g$ and the value of its Fourier expansion $f$ and between the derivatives of $g$ and the derivatives of $f$ can be minimized to an arbitrary degree over the range of the function by choosing $J$ to be sufficiently large. It thus provides a global approximation to the true function, rather than a local approximation (as in a Taylor series expansion). We selected $J$ by crossvalidation, minimizing the sum of the squared prediction errors $\sum\left(y_{i}-\hat{y}_{-i}\right)^{2}$, where $\hat{y}_{-i}$ is the leave-one-out prediction generated by omitting observation $i$ from the regression. ${ }^{14}$

\footnotetext{
${ }^{13}$ For example, Wolff et al. (2004) multiplied this wage by a performance index that depends on household-level characteristics as well as characteristics of household members.

${ }^{14}$ Andrews (1991) shows this criterion is asymptotically optimal in the sense that the probability of choosing the $J$ that minimizes the expected sum of squared errors converges to 1 as the sample size increases, even in the presence of heteroscedasticity.
} 
Using the flexible functional form in (1), we estimate the following equation to impute household production:

$$
P_{i t}^{d}=f\left(Z_{i}, X_{i}\right)+u_{i t}^{d} \quad(d=D, E),
$$

where separate equations were estimated for weekdays $(D)$ and weekends $(E)$ for each sex $\times$ marital status cell (eight regressions total). For each cell, we combine the predicted values from the weekday and weekend equations to generate imputed weekly value of household production for person $i$ as follows:

$$
\hat{P}_{i}=5 \hat{f}_{D}\left(Z_{i}, X_{i}\right)+2 \hat{f}_{E}\left(Z_{i}, X_{i}\right),
$$

where $X$ is appropriately defined for each equation. For married households, total household production is simply the sum of the husband's and wife's predicted values. We set predicted production equal to zero for values where $\hat{P}_{i}$ is less than zero (only three observations required this).

We implemented this procedure as follows. Our first step was to use the 2,639 observations with valid income data in their March CPS interviews to estimate equation (2) for each of the sex $\times$ marital status $\times$ day cells, and determine the optimal value of $J$ in (1).$^{15}$ Next, we reestimated (2) over the entire sample using the optimal value of $J .^{16}$ For these regressions, we imputed income for observations that could not be matched to March or had allocated income in March. ${ }^{17}$ Coefficient estimates from these regressions were used to generate imputed values of household production in (3). Our extended income measure is computed for the 3,329 values

\footnotetext{
${ }^{15}$ The number of observations for these regressions ranged from 180 (for single men on weekdays) to 468 (married women on weekends).

${ }^{16}$ For these regressions, the sample sizes ranged from 599 to 1,831 .

${ }^{17}$ Family income was imputed using predicted values from a regression of income on covariates. As noted in Greene (2000, p. 363), including observations with imputed family income increases does not change the coefficient on family income, but it does increase the precision of the coefficients on the other variables.
} 
matched to the March supplement as the sum of family income from March, including allocated values, and imputed household production. We used ATUS sample weights throughout the analysis. Weighting is necessary to correct for the stratification of the sample and for differential response rates across groups. ${ }^{18}$

As noted in the Introduction, this imputation procedure eliminates deviations from the conditional mean of household production, which could bias estimates of income inequality. Therefore, we assess the potential bias by adding a random perturbation and recomputing the inequality measures. The first step is to derive an estimate of the upper bound for the variance of the long-term household production that was eliminated in the imputation procedure. It is useful to decompose the residual in (2) into two components as follows:

$$
P_{i t}^{d}=f_{d}\left(Z_{i}, X_{i}\right)+\left(m_{i}^{d}+e_{i t}^{d}\right) \quad(d=D, E)
$$

where the residual is equal to the sum of a person-specific fixed effect $\left(m_{i}^{d}\right)$ and a term denoting day-to-day variation $\left(e_{i t}^{d}\right) .{ }^{19}$ If the $\operatorname{Var}\left(m_{i}^{d}\right)=0$, the residual consists entirely of day-to-day variation in household production, and our imputation procedure will generate consistent estimates of long-run household production for each observation in the sample, which in turn will result in consistent estimates of inequality measures for extended income. However, if $\operatorname{Var}\left(m_{i}^{d}\right)>0$, our procedure will underestimate the variability of long-run household production across households and will usually generate downwardly biased inequality measures.

We can use the residuals from (2) to place an upper bound on the variance of long-run household production. Letting $\sigma_{d}(d=D, E)$ denote the standard deviation of the residual in (2)

\footnotetext{
${ }^{18}$ Details on ATUS sampling and weighting procedures are contained in Bureau of Labor Statistics (2007).

${ }^{19}$ More precisely, $m_{i}$ is the long-run average of $P_{i t}-f\left(X_{i}, Z_{i}\right)$. We do not assume that the $e_{i t}$ are independent across time.
} 
for weekdays and weekends, the maximum possible variance for long-run weekly household production (i.e., assuming $\left.\operatorname{Var}\left(e_{i t}^{d}\right)=0\right)$ is $M=\left(5 \sigma_{D}+2 \sigma_{E}\right)^{2}$. Thus $0 \leq \operatorname{Var}\left(m_{i}^{d}\right) \leq M$. We generate perturbed values of imputed household production for single-person households by using:

$$
P_{i}^{S}=5 \hat{f}_{D}\left(X_{i}\right)+2 \hat{f}_{E}\left(X_{i}\right)+k s_{i}
$$

where $0<k \leq 1$ and $s_{\mathrm{i}}$ is drawn from $N(0, M)$.

For married-couple households, the maximum possible variance for long-run production across households occurs when the residuals for spouses' production are perfectly positively correlated. Extending the definition of the maximum residual variance $M$ to include spouses, we have: $M^{\prime}=\left(5\left[\sigma_{D w}+\sigma_{D h}\right]+2\left[\sigma_{E w}+\sigma_{E h}\right]\right)^{2}$ where $\sigma_{d s}$ is the standard deviation of the residuals from the married-couple versions of (2) and subscripts denote day of week $(d=D, E)$ and spouse $(s=w, h)$. Total production is

(6) $P_{i}^{M}=5 \hat{f}_{D w}\left(Z_{i}, X_{i}\right)+2 \hat{f}_{E w}\left(Z_{i}, X_{i}\right)+5 \hat{f}_{D h}\left(Z_{i}, X_{i}\right)+2 \hat{f}_{E h}\left(Z_{i}, X_{i}\right)+k s_{i}{ }^{\prime}$, where $s_{i}^{\prime}$ is drawn from $N\left(0, M^{\prime}\right)$. We computed our inequality measures assuming $k=0, k=$ $0.25, k=0.50$, and $k=1.0$ for both singles and married couples.

This approach generalizes methods used in the previous literature. Using predicted values alone, as in Bonke (1992) and Bryant and Zick (1985), is equivalent to $k=0$. The approach using the regression residual or the observed value, as in Jenkins and O'Leary (1996) and Bonke, Deding, and Lausten (2004), implicitly sets $k=1$.

The framework used here (equation (4)) allows us to assess the value of using datasets like those used in Jenkins and O'Leary (1996) and Bonke, Deding, and Lausten (2004) that collect diaries for more than one day per person. In these types of datasets, day-to-day variation 
$\left(\operatorname{Var}\left(e_{i t}^{d}\right)\right)$ is a smaller component of the total residual variation $\left(\operatorname{Var}\left(m_{i}^{d}\right)+\operatorname{Var}\left(e_{i t}^{d}\right)\right)$, because day-to-day differences tend to average out. However, no existing time-diary survey collects data covering a long enough period to completely eliminate day-to-day variation, so that using actual values or the residual always exaggerates the variance of long-run household production. Thus, except for precision, the use of predicted values to impute household production is unaffected by the number of diary days per person. Similarly, collecting data from everybody in the household increases precision, but does not otherwise improve imputed values.

Finally, to account for different household sizes, we adjusted extended income measures using two alternative equivalence scales. The first is the OECD equivalence scale (OECD, 2005), which is given by: $E=I /(1.0+0.7(A-1)+0.5 C)$, where $E$ is equivalent income, $I$ is the income measure, $A$ is the number of adults in the household (either one or two in our case) and $C$ is the number of children less than 18 . The second is: $E=I / \sqrt{A+C}$.

\section{Results}

Table 1 shows means and standard deviations for our OECD equivalent household production measure for the four definitions of household production as defined by whether the specialist or generalist wage was used and whether secondary childcare is included or excluded (results are similar for the square-root scale). We show average values of both imputed household production ${ }^{20}$ for our main sample $(n=3,329)$ and actual household production for any ATUS sample members who fit the age and household composition criteria $(n=10,984)$.

\footnotetext{
${ }^{20}$ We predict the equivalence-scale normalized value of household production directly rather than actual time spent in household production. Let $\mathrm{P}_{\mathrm{i}}=\mathrm{w}_{\mathrm{i}} \mathrm{H}_{\mathrm{i}}$ denote the normalized amount of time spent in household production for household $i$, where $\mathrm{w}_{\mathrm{i}}$ is the normalizing factor for the equivalence scale and $H_{i}$ is hours of production. Then $\mathrm{E}\left(\mathrm{P}_{\mathrm{i}} \mid \mathrm{X}\right)$ $\neq \mathrm{w}_{\mathrm{i}} \mathrm{E}\left(\mathrm{H}_{\mathrm{i}} \mid \mathrm{X}\right)$. Thus regressing hours of production on the covariates and then applying the equivalence scale will not yield a consistent estimate of normalized production.
} 
Total household production for married couples is simply the sum of married men's and married women's household production. Because the ATUS collects data from only one person per household, we do not directly observe household production for married couples and cannot compute standard deviations for their actual household production.

The results by household type and sex accord with our expectations. Households of single adults produce less than married-couple households even on an equivalence-scalenormalized basis. Women produce more than men; if secondary childcare is excluded the ratio of women's to men's production is greater in married couples than for singles. There is a fair amount of variation in the imputed values of household production, though it is small relative to the mean and less than the variation in actual values. Comparing the means of imputed and actual household production reveals that the differences are very small (less than one percent for most groups), with single men exhibiting the largest differences (just under 4 percent).

Table 2 shows person-weighted estimates of the mean value of household production and household earnings. ${ }^{21}$ Under all measures, household production is a substantial fraction of household money earnings, from 31 percent (using the generalist wage and excluding secondary childcare) to 47 percent (specialist wages and including secondary childcare). Put differently, household production comprises 23-32 percent of combined labor earnings and household production. Household production is a higher fraction of extended income for married couples than for single households, equaling 32-49 percent of money income for married couples compared to 24-32 percent for singles.

Table 3 presents results for five commonly-used inequality measures: the coefficient of variation, the Gini coefficient, and the ratios of the $90^{\text {th }}$ to the $50^{\text {th }}$ percentile, the $50^{\text {th }}$ to the $10^{\text {th }}$

\footnotetext{
${ }^{21}$ All of our estimates are person weighted, rather than household weighted.
} 
percentile, and the $90^{\text {th }}$ to the $10^{\text {th }}$. All five are conventional, and similar measures are used in Jenkins and O'leary (1996). The measures differ in the sensitivity of measured inequality to changes at different points in the income distribution. Atkinson (1970) points out that the Gini will be particularly sensitive to variation in the middle of the distribution, whereas the coefficient of variation will attach equal weight to the entire range of the distribution. The ratios of percentiles allow comparisons at different points in the distribution and are commonly reported indicators of trends in inequality (see DeNavas-Walt et al. (2007), Table A3, for example).

As expected, moving from money income to extended income (that is, from row 1 to row 2 for each measure) substantially reduces measured inequality. Both the coefficient of variation and the Gini coefficient fall by about one-quarter regardless of whether the OECD or the square root scale is used. The effect on the 50/10 and 90/10 ratios are also quite dramatic, with the ratios falling by about one-third and one-half, respectively, under both scales. The effect on the 90/50 ratio is somewhat smaller, with the ratio falling by about one-fifth under both scales. (All of these differences are statistically significant at the 1 percent level.) The larger effects on the 50/10 and 90/10 ratios compared with the 90/50 ratio are not surprising, because we would expect household production income to be a larger fraction of extended income for those who are lower in the money income distribution. Thus, it is clear from Table 3 that the finding that household production reduces measured inequality is robust to the inequality measure used.

Relative inequality measures such as the Gini coefficient will always fall if a positive constant is added to the income of all members of the population. Jenkins and O'Leary (1996) pointed out that inequality of extended income is positively related to the variance of household production and the correlation between money income and household production. In our data, this correlation ranges from -0.10 to 0.20 across extended income measures and equivalence 
scales. Using specialist wages increases the correlation, while including secondary child care reduces the correlation. Gottschalk and Mayer (2002) also found a weak relationship between money income and household production, with high-money-income households spending more time in household production. This positive correlation would seem to imply that including household production should increase measured inequality. But the fraction of extended income accounted for by household production income is so much higher for low-money-income households that this effect dwarfs differences in the amount of time spent in household production by income level.

To investigate this further, we recomputed extended income by adding overall mean household production income, rather than imputed values, to household money income (row 3 of Table 3). The results are striking. As we would expect, the inequality measures are generally smaller when using mean household production income, ${ }^{22}$ but the differences between rows (2) and (3) are quite small. Some of the differences are statistically significant, but none are economically significant. Thus, virtually all of the reduction in measured inequality when going from money income to extended income is due to the addition of mean household production income--very little of this reduction is due to the correlation between money income and household production income.

The inclusion of secondary childcare and to a lesser extent the use of specialist rather than generalist wages both tend to reduce measured inequality. In both cases this is mostly due to greater mean levels of household production. For most comparisons, it makes little difference whether the square root or OECD equivalence scale is used. The most notable exception is the

\footnotetext{
${ }^{22}$ There are only two instances (both using the 90/50 ratio) where the predicted-household-production extended income (row 2) inequality measure is less than the corresponding mean-household-production measure (row 3 ) by a statistically significant amount.
} 
50/10 ratio when secondary childcare is included (both using generalist and specialist wages).

The decline in inequality is larger when using the OECD scale than when using the square root scale. And the difference between the predicted-household-production and the mean-householdproduction measures is smaller for the OECD scale.

Rows 4-6 of Table 3 show the effect of adding normally-distributed random disturbances to predicted household production as in equations (5) and (6). The results in row $6(k=1)$ assume no day-to-day variation and are upper bounds on the effect of the perturbations. We will focus on the results in rows 4 and $5(k=0.25$ and $k=0.50)$, which were generated under more realistic assumptions. In cases where adding the disturbance implied a negative value for household production, the value was set to zero. Adding the disturbances increases the variance of household production but reduces the magnitude of the correlation with money income, so the predicted direction of the effect is ambiguous if the correlation is negative. We find that in almost all cases, adding the disturbance increases the inequality of extended income, frequently to the extent that the inequality measures in rows 4-6 are statistically significantly greater than the constant-household-production measure in row 3 . However, the differences for rows 4 and 5 are rather small and are not economically significant.

Thus far we have shown that the lower measured inequality of extended income, compared to money income, is due to the addition of mean household production, rather than to the substitution of household production for market work. Given the small correlation between the value of household production and money income, it is natural to wonder by how much measured inequality would change if the correlation were large in magnitude.

For convenience, we confine ourselves to the coefficient of variation (CV) and note that

$$
C V^{2}=\frac{\sigma_{E}^{2}}{\bar{E}^{2}}=\frac{\sigma_{Y}^{2}+2 \sigma_{Y P}+\sigma_{P}^{2}}{\bar{E}^{2}}=\frac{\sigma_{Y}^{2}+2 \rho \sigma_{Y} \sigma_{P}+\sigma_{P}^{2}}{\bar{E}^{2}},
$$


where $\bar{E}$ is the mean of extended income; the subscripts on the variance and covariance terms denote money income $(Y)$, household production $(P)$, and extended income $(E)$; and $\rho$ is the correlation between money income and household production. As noted above, the correlation varies from -0.12 to 0.10 depending on the household production measure and equivalence scale used.

Table 4 shows the variation of the $\mathrm{CV}$ across values of $\rho$ and $\sigma_{P}^{2}$ using the specification for which $\mathrm{CV}$ is most sensitive to changes in $\rho$ (using the specialist wage and the square root equivalence scale, and including secondary child care). The rows in Table 4 correspond to those in Table 3. The first column of Table 4 replicates estimates from the last column of Table 3 , in which the overall correlation between household production income and money income is -0.028 . The slight difference between the Table 3 and Table 4 estimates arises because we used equation (7) to compute the estimates in Table 4, rather than simulating the disturbances as was done in Table 3. Examining the rows, we can see that, for a given value of $\sigma_{P}$, the $\mathrm{CV}$ increases monotonically as $\rho$ increases from -1 to 1 . Looking down each column of Table 4 , we can see how the $\mathrm{CV}$ varies with $\sigma_{P}$ holding $\rho$ constant. The relationship between the $\mathrm{CV}$ and $\sigma_{P}$ depends on the value of $\rho$. However, large values of $\sigma_{P}$ increase $\mathrm{CV}$ when $\rho$ is positive and decrease $\mathrm{CV}$ when $\rho$ is negative and sufficiently large.

The most prominent result in Table 4 is that the $\mathrm{CV}$ of extended income is always less than the $\mathrm{CV}$ of money income. This is true even for the extreme case where $\rho=1$ and $k=1$. Furthermore, the implied elasticities of the $\mathrm{CV}$ with respect to $\rho$ (in a neighborhood around $\rho=$ 0.1 ) and $\sigma_{P}$ (in a neighborhood around 0.25 ) are less than 0.05 , which implies that changes in $\rho$ 
and $\sigma_{P}$ over time, unless they are very large, should have negligible effects on measured inequality.

The result that extended income is more equally distributed than money income even when $\rho=1$ may seem counterintuitive. But as is clear from (7), the CV depends on the variance of household production as well as the correlation between money and household production. The small variance of household production limits the amount to which money income and household production can covary. Another way of seeing this is to consider the coefficient of a regression of household production income on money income, $\beta \equiv \sigma_{Y P} / \sigma_{Y}^{2}$. The coefficient $\beta$ is a convenient measure of the relationship between household production and money income, as it represents the amount by which household production increases or decreases for a dollar increase in money income. The Cauchy-Schwarz inequality implies that the maximum possible value of $\beta$ is $\sigma_{P} / \sigma_{Y}$, as larger values imply a value of $\rho$ greater than 1 . Thus the small variance of household production relative to money income places an upper bound on the extent to which household production varies with money income. In the extreme case where $k=1$, the upper bound on $\beta$ is 0.34 , which implies that the data are consistent with at most a moderate association between money income and household production.

This result is not limited to our data. We performed an exercise similar to Table 4 using estimates from Jenkins and O'Leary (1996), as all necessary numbers for the calculation are listed in their Tables 1 and 2. The results are similar. Using the housekeeper wage as in the text, the CV of money income for all households in Jenkins and O'Leary's data is 0.648 . As the correlation of money income with household income varies between the two extreme values of -1 and 1 , the CV of extended income varies from 0.199 to 0.497 . 
Our sensitivity analysis makes it clear that, given the variability of household production in the data, the $\mathrm{CV}$ is not sensitive to the correlation between household production and money income. Given our earlier finding that it is the addition of a large constant--the value of household production--to income that causes extended income to be more equally distributed than money income, it is only natural to ask: How sensitive is the CV to the mean value of household production? From equation (7), we can easily derive the elasticity of the CV with respect to the value of household production, $\varepsilon(\mathrm{CV}, P)=-\bar{P} / \bar{E}$. Using data from Table 2, this elasticity ranges from 0.23 to 0.32 depending on whether secondary childcare is included and whether a specialist or generalist wage is used. Thus, the CV is much more sensitive to the mean value of household production than it is to the variation of household production around the mean.

\section{Conclusion}

The main contribution of our paper is to show why extended income is more equally distributed than money income. Our findings clearly demonstrate that the more-equal distribution of extended income compared to money income is due to the addition of a large constant--the mean value of household production income--to each household's money income, and that it is not due to the weak correlation between money and household production income

as speculated by Jenkins and O'Leary (1996). Our sensitivity analysis showed that the effect of adding this constant is so large that extended income would be more equally distributed than money income even if the variability of household production were at the maximum value that is consistent with our data and household production and money income were perfectly positively correlated. Our results also show that measured inequality is sensitive to changes in mean 
household production, but is not sensitive to changes in the standard deviation of household production income between households and the correlation between household production and money income. A 10 percent change in the mean value of household production will translate to a 2-3 percent change in the $\mathrm{CV}$, whereas the same relative change in the standard deviation of household production or the correlation between household production and money income translates into a change of less than one half of one percent.

These results are important to researchers who are interested in examining trends in extended-income inequality, because time-use surveys are often conducted only periodically and the variables available for imputation are not the same between surveys. We showed that it is much more important to correctly estimate the mean value of household production than to correctly estimate the relationship between household production and money income. Our results also imply that, because inequality measures are not sensitive to the relationship between household production and money income, differences in the variables available for imputation will have little effect on measured trends. Any true changes in the variance of household production across households or in the relationship between money income and the value of household production are likely to have such a small effect on measured trends that they can safely be ignored. 


\section{References}

Andrews, Donald W.K. (1991) "Asymptotic Optimality of Generalized CL, Cross-validation, and Generalized Cross-validation in Regression with Heteroskedastic Errors." Journal of Econometrics 47, 359-377.

Atkinson, Anthony B., (1970). "On the measurement of inequality," Journal of Economic Theory 2(3), pp 244-263.

Becker, Gary (1965) “A Theory of the Allocation of Time.” Economic Journal 75(299), September 1965, pp. 493-517.

Bonke, Jens (1992) "Distribution of Economic Resources: Implications of Including Household Production." Review of Income and Wealth 38(3), September 1992, pp. 281-293.

Bonke, Jens, Mette Deding, and Mette Lausten (2004) "Time and Money - Are They Substitutes?" Paper presented at the $28^{\text {th }}$ General Conference of The International Association for Research in Income and Wealth.

Bryant, Keith and Cathleen Zick (1985) "Income Distribution Implications of Rural Household Production." American Journal of Agricultural Economics 67(5) Proceedings Issue, December 1985, pp. 1100-1104

Bureau of Labor Statistics (2007). American Time Use Survey User's Guide. December 2007.

DeNavas-Walt, Carmen, Bernadette D. Proctor, and Jessica Smith. (2007) U.S. Census Bureau, Current Population Reports, P60-233, Income, Poverty, and Health Insurance Coverage in the United States: 2006. U.S. Government Printing Office, Washington, DC.

Frazis, Harley and Jay Stewart (2004) "Where Does the Time Go? Concepts and Measurement in the American Time Use Survey." Forthcoming in Hard to Measure Goods and Services: Essays in Memory of Zvi Griliches, edited by Ernst Berndt and Charles Hulten. NBER Studies in Income and Wealth, University of Chicago Press.

Gallant, A. Ronald. (1981) "On the Bias in Flexible Functional Forms and an Essentially Unbiased Form: The Fourier Flexible Form." Journal of Econometrics 15, pp. 211-245.

Gottschalk, Peter and Susan Mayer (2002) "Changes in Home Production and Trends in Economic Inequality." in The New Economics of Rising Inequalities edited by Daniel Cohen, Thomas Piketty, and Gilles Saint-Paul. Oxford University Press.

Gottschalk, Peter and Timothy Smeeding (1997) "Cross-National Comparisons of Earnings and Income Inequality.” Journal of Economic Literature 35(2), June 1997), pp. 633-687.

Greene, William H. (2000) Econometric Analysis, 4th edition. Upper Saddle River, New Jersey: Prentice Hall.

Gronau, Reuben (1980) "Home Production -- A Forgotten Industry." Review of Economics and Statistics 62(3), August 1980, pp. 408-416.

Gronau, Reuben (1986) "Home Production -- A Survey." in Handbook of Labor Economics edited by Orley Ashenfelter and Richard Layard. Amsterdam, North Holland. 
Jenkins, Stephen and Nigel O'Leary (1996) "Household Income Plus Household Production: The Distribution of Extended Income in the U.K." Review of Income and Wealth 42(4), December 1996, pp. 401-419.

Johnson, David, and Stephanie Shipp (1997) "Trends in Inequality Using ConsumptionExpenditures: The U.S. From 1960 to 1993." Review of Income and Wealth 43(2), June 1997, pp. 133-152.

Johnson, David, and Stephanie Shipp (1997) "Trends in Inequality Using Consumer Expenditures: 1960 to 1993." Proceedings of the Section on Survey Methods Research, American Statistical Association, Alexandria, Virginia.

Johnson, David, Timothy Smeeding, and Barbara Boyle Torrey (2005) "Economic Inequality Through the Prisms of Income and Consumption.” Monthly Labor Review 128(4), April 2005, pp. 11-24.

Krueger, Dirk, and Fabrizio Perri (2002) "Does Income Inequality Lead to Consumption Inequality? Evidence and Theory." NBER Working Paper No. 9202.

Organisation for Economic Co-operation and Development. (2005) "What Are Equivalence Scales". Mimeo.

Pierce, Brooks (2001) “Compensation Inequality.” Quarterly Journal of Economics 116(4), November 2001, 1493-1525.

Wolff, Edward, Ajit Zacharias, and Asena Caner (2003) "Levy Institute Measure of Economic Well-Being: United States, 1989 and 2000." Unpublished report. The Levy Economics Institute of Bard College.

Wolff, Edward, Ajit Zacharias, and Asena Caner (2004) "Levy Institute Measure of Economic Well-Being: Concept, Measurement, and Findings: United States, 1989 and 2000." Unpublished report. The Levy Economics Institute of Bard College. 
Table 1: Means and Standard Deviations, Normalized Household Production for Different Production Measures and Household Types using the OECD Equivalence Scale

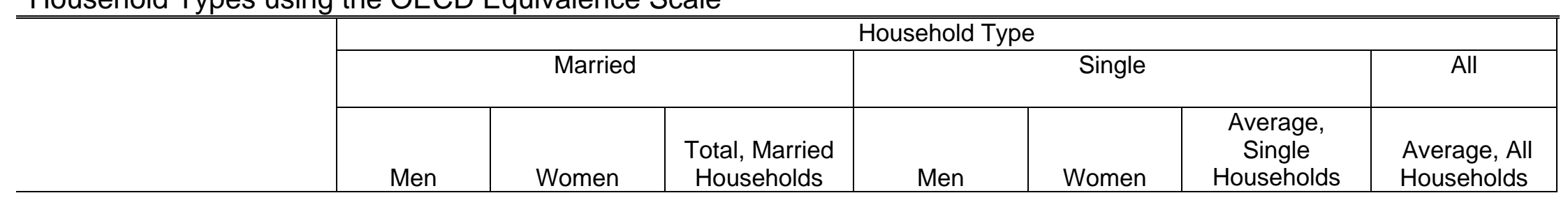

Generalist

Wage

Secondary Actual

Childcare

Excluded

$\begin{array}{rr}4,211 & 7,201 \\ (4,471) & (4,813)\end{array}$

$\begin{array}{rr}6,531 & 8,875 \\ (7,900) & (8,210)\end{array}$

7,846

10,500

Imputed

$\begin{array}{rr}4,241 & 7,142 \\ (1,694) & (1,561)\end{array}$

11,383

$(7,900)$

$(8,157)$

$(1,694)$

$(1,768)$

6,298

9,053

7,784

10,440

Secondary

Actual

Childcare

$\begin{array}{rrr} & 6,213 & 9,875 \\ & (5,747) & (6,157) \\ & & \\ \text { Imputed } & 6,232 & 9,831 \\ & (1,829) & (3,041)\end{array}$

$(5,747)$

$(6,157)$

16,087

$(2,165)$

$(2,386)$

$(2,667)$

$(2,583)$

Included

9,831
$(3,041)$

16,064

7,113

10,811

9,189

$(9,014)$

14,340

$(1,829)$

(4,311)

6,847

10,968

9,070

14,232

$(2,836)$

$(3,123)$

$(3,630)$

$(5,160)$ 
Table 1: Means and Standard Deviations, Imputed Normalized Household Production for Different Production Measures and Household Types using the OECD Equivalence Scale, continued

\begin{tabular}{|c|c|c|c|c|c|c|c|c|}
\hline & & \multicolumn{7}{|c|}{ Household Type } \\
\hline & & \multicolumn{3}{|c|}{ Married } & \multicolumn{3}{|c|}{ Single } & \multirow{2}{*}{$\begin{array}{c}\text { All } \\
\text { Average, All } \\
\text { Households }\end{array}$} \\
\hline & & Men & Women & $\begin{array}{c}\text { Total, Married } \\
\text { Households }\end{array}$ & Men & Women & $\begin{array}{c}\text { Average, } \\
\text { Single } \\
\text { Households }\end{array}$ & \\
\hline \multirow{2}{*}{\multicolumn{9}{|c|}{$\begin{array}{l}\text { Specialist } \\
\text { Wage }\end{array}$}} \\
\hline & & & & & & & & \\
\hline \multicolumn{9}{|l|}{$\begin{array}{l}\text { Secondary } \\
\text { Childcare }\end{array}$} \\
\hline Childcare & & & & & & & & \\
\hline \multirow[t]{4}{*}{ Excluded } & & 4,890 & 7,585 & 12,475 & 7,487 & 9,579 & 8,661 & 11,504 \\
\hline & & $(5,632)$ & $(5,301)$ & & $(9,813)$ & $(9,475)$ & $(9,679)$ & \\
\hline & Imputed & 4,863 & 7,518 & 12,381 & 7,181 & 9,813 & 8,601 & 11,391 \\
\hline & & $(1,338)$ & $(1,618)$ & $(1,947)$ & $(2,725)$ & $(2,829)$ & $(3,075)$ & $(2,835)$ \\
\hline \multirow{6}{*}{$\begin{array}{l}\text { Secondary } \\
\text { Childcare } \\
\text { Included }\end{array}$} & Actual & & & & & & & \\
\hline & & & & & & & & \\
\hline & & 6,812 & 10,173 & 16,984 & 8,004 & 11,591 & 9,950 & 15,190 \\
\hline & & $(6,556)$ & $(6,441)$ & & $(9,998)$ & $(10,152)$ & $(10,297)$ & \\
\hline & Imputed & 6,775 & 10,104 & 16,879 & 7,708 & 11,654 & 9,837 & 15,034 \\
\hline & & $(1,814)$ & $(2,942)$ & $(4,029)$ & $(3,214)$ & $(3,339)$ & $(3,826)$ & $(5,040)$ \\
\hline
\end{tabular}


Table 2: Mean Annual Household Earnings and Household Production for Different Production Measures

\begin{tabular}{|c|c|c|c|c|c|c|}
\hline & & & \multicolumn{4}{|c|}{ Household Production } \\
\hline & & & \multicolumn{2}{|c|}{ Generalist Wage } & \multicolumn{2}{|c|}{ Specialist Wage } \\
\hline & & & $\begin{array}{l}\text { Secondary } \\
\text { Childcare } \\
\text { Excluded }\end{array}$ & $\begin{array}{c}\text { Secondary } \\
\text { Childcare } \\
\text { Included }\end{array}$ & $\begin{array}{l}\text { Secondary } \\
\text { Childcare } \\
\text { Excluded }\end{array}$ & $\begin{array}{c}\text { Secondary } \\
\text { Childcare } \\
\text { Included }\end{array}$ \\
\hline & $\begin{array}{c}\text { Household } \\
\text { Money } \\
\text { Earnings }\end{array}$ & $\begin{array}{c}\text { Money } \\
\text { Earnings } \\
\text { Normalized } \\
\text { by OECD } \\
\text { Equivalence } \\
\text { Scale }\end{array}$ & & & & \\
\hline All & & & & & & \\
\hline $\begin{array}{l}\text { Households } \\
\text { Single- } \\
\text { person }\end{array}$ & 70,553 & 37,621 & 10,440 & 14,232 & 11,391 & 15,034 \\
\hline $\begin{array}{l}\text { Households } \\
\text { Married- } \\
\text { couple }\end{array}$ & 38,689 & 36,078 & 7,784 & 9,070 & 8,601 & 9,837 \\
\hline Households & 81,863 & 38,169 & 11,383 & 16,064 & 12,381 & 16,879 \\
\hline
\end{tabular}

Note: Household production estimated using the OECD equivalence scale.

The square-root equivalence scale gives similar results. Data are from the 2003

ATUS. 
Table 3: Inequality Measures for Different Measures of Household Income

\begin{tabular}{|c|c|c|c|c|c|c|c|c|}
\hline & \multicolumn{4}{|c|}{ Generalist Wage } & \multicolumn{4}{|c|}{ Specialist Wage } \\
\hline & \multicolumn{2}{|c|}{$\begin{array}{c}\text { Secondary Childcare } \\
\text { Excluded }\end{array}$} & \multicolumn{2}{|c|}{$\begin{array}{c}\text { Secondary Childcare } \\
\text { Included }\end{array}$} & \multicolumn{2}{|c|}{$\begin{array}{c}\text { Secondary Childcare } \\
\text { Excluded }\end{array}$} & \multicolumn{2}{|c|}{$\begin{array}{c}\text { Secondary Childcare } \\
\text { Included }\end{array}$} \\
\hline & $\begin{array}{c}\text { OECD } \\
\text { Equivalence } \\
\end{array}$ & $\begin{array}{c}\text { Sq. Root } \\
\text { Equivalence }\end{array}$ & $\begin{array}{c}\text { OECD } \\
\text { Equivalence } \\
\end{array}$ & $\begin{array}{c}\text { Sq. Root } \\
\text { Equivalence }\end{array}$ & $\begin{array}{c}\text { OECD } \\
\text { Equivalence } \\
\end{array}$ & $\begin{array}{c}\text { Sq. Root } \\
\text { Equivalence }\end{array}$ & $\begin{array}{c}\text { OECD } \\
\text { Equivalence } \\
\end{array}$ & $\begin{array}{c}\text { Sq. Root } \\
\text { Equivalence }\end{array}$ \\
\hline \multicolumn{9}{|l|}{ Coefficient of Variation } \\
\hline (1) Family income & $0.942^{\star \star}$ & $0.917^{* *}$ & $0.942^{\star *}$ & $0.917^{* *}$ & $0.942^{\star \star}$ & $0.917^{\star \star}$ & $0.942^{\star \star}$ & $0.917^{* *}$ \\
\hline$(2)=(1)+$ Pred. $\mathrm{HH}$ production & 0.741 & 0.720 & 0.679 & 0.663 & 0.730 & 0.710 & 0.671 & 0.655 \\
\hline$(3)=(1)+$ Mean HH prod. & 0.738 & 0.714 & 0.684 & 0.657 & 0.723 & 0.700 & 0.673 & 0.647 \\
\hline$(4)=(2)+.25 \mathrm{~S}$ & 0.742 & 0.722 & 0.680 & 0.665 & 0.731 & 0.712 & 0.672 & 0.657 \\
\hline$(5)=(2)+.5 \mathrm{~S}$ & 0.745 & 0.725 & 0.684 & $0.669 *$ & 0.735 & 0.716 & 0.677 & $0.662^{*}$ \\
\hline$(6)=(2)+S$ & $0.756^{\star \star}$ & $0.737^{\star \star}$ & $0.699 *$ & $0.685^{\star *}$ & $0.749 *$ & $0.732^{\star \star}$ & $0.695^{\star \star}$ & $0.681^{* *}$ \\
\hline \multicolumn{9}{|l|}{ Gini } \\
\hline (1) Family income & $0.416^{\star *}$ & $0.409 * *$ & $0.416^{\star *}$ & $0.409 * *$ & $0.416^{\star *}$ & $0.409 * *$ & $0.416^{\star *}$ & $0.409 * *$ \\
\hline$(2)=(1)+$ Pred. $\mathrm{HH}$ production & 0.328 & $0.324^{\star *}$ & 0.299 & $0.301^{\star \star}$ & $0.324^{\star \star}$ & $0.320 * *$ & 0.297 & $0.298^{\star *}$ \\
\hline$(3)=(1)+$ Mean HH prod. & 0.325 & 0.318 & 0.302 & 0.293 & 0.319 & 0.312 & 0.297 & 0.288 \\
\hline$(4)=(2)+.25 \mathrm{~S}$ & $0.329 *$ & $0.325^{\star *}$ & 0.301 & $0.302^{* *}$ & $0.326^{* *}$ & $0.321 * *$ & 0.299 & $0.300 * *$ \\
\hline$(5)=(2)+.5 \mathrm{~S}$ & $0.332^{\star *}$ & $0.328 * \star$ & 0.305 & $0.306^{\star \star}$ & 0.330 ** & $0.326^{\star \star}$ & $0.304^{\star *}$ & $0.305^{\star \star}$ \\
\hline$(6)=(2)+S$ & $0.340 * *$ & $0.336^{\star *}$ & $0.317^{* *}$ & $0.318^{* *}$ & $0.339 * *$ & $0.336^{\star *}$ & $0.317^{* *}$ & $0.318^{* *}$ \\
\hline \multicolumn{9}{|l|}{$90^{\text {th }}$ percentile $/ 50^{\text {th }}$ percentile } \\
\hline (1) Family income & $2.416^{\star \star}$ & $2.355^{\star \star}$ & $2.416^{\star *}$ & $2.355^{\star *}$ & $2.416^{\star \star}$ & $2.355^{\star \star}$ & $2.416^{\star \star}$ & $2.355^{\star *}$ \\
\hline$(2)=(1)+$ Pred. $\mathrm{HH}$ production & 2.029 & 1.978 & $1.905^{\star}$ & 1.879 & 2.002 & 1.956 & $1.894^{*}$ & 1.854 \\
\hline$(3)=(1)+$ Mean HH prod. & 2.046 & 1.998 & 1.955 & 1.904 & 2.021 & 1.975 & 1.938 & 1.889 \\
\hline$(4)=(2)+.25 \mathrm{~S}$ & 2.042 & 1.997 & $1.913^{*}$ & 1.881 & 2.014 & 1.980 & $1.900 *$ & 1.859 \\
\hline$(5)=(2)+.5 \mathrm{~S}$ & 2.041 & 2.007 & $1.913^{*}$ & 1.883 & 2.018 & 1.990 & 1.904 & 1.870 \\
\hline$(6)=(2)+S$ & 2.042 & 2.014 & 1.928 & 1.911 & 2.029 & 2.007 & 1.923 & 1.910 \\
\hline \multicolumn{9}{|l|}{$50^{\text {th }}$ percentile $/ 10^{\text {th }}$ percentile } \\
\hline (1) Family income & $3.231^{\star \star}$ & $3.216^{\star \star}$ & $3.231^{\star *}$ & $3.216^{\star \star}$ & $3.231^{\star *}$ & $3.216^{\star \star}$ & $3.231^{\star *}$ & $3.216^{\star \star}$ \\
\hline$(2)=(1)+$ Pred. $\mathrm{HH}$ production & 2.039 & 2.041 & 1.880 & $2.031^{\star *}$ & 2.027 & 2.024 & 1.877 & $2.019 * \star$ \\
\hline$(3)=(1)+$ Mean HH prod. & 2.040 & 2.030 & 1.871 & 1.851 & 1.992 & 1.983 & 1.843 & 1.824 \\
\hline$(4)=(2)+.25 \mathrm{~S}$ & 2.063 & 2.083 & 1.880 & $2.044^{\star *}$ & 2.065 & 2.077 & 1.884 & $2.042^{\star *}$ \\
\hline$(5)=(2)+.5 \mathrm{~S}$ & $2.110^{*}$ & $2.156^{\star \star}$ & $1.943^{* *}$ & $2.094^{\star *}$ & $2.132^{\star *}$ & $2.167^{\star *}$ & $1.955^{\star *}$ & $2.100^{\star *}$ \\
\hline$(6)=(2)+S$ & $2.269 * \star$ & $2.319 * \star$ & $2.139 * *$ & $2.255^{\star \star}$ & $2.310^{\star \star}$ & $2.346^{\star \star}$ & $2.175^{\star \star}$ & $2.284^{\star *}$ \\
\hline
\end{tabular}


Table 3: Inequality Measures for Different Measures of Household Income (continued)

\begin{tabular}{|c|c|c|c|c|c|c|c|c|}
\hline & \multicolumn{4}{|c|}{ Generalist Wage } & \multicolumn{4}{|c|}{ Specialist Wage } \\
\hline & \multicolumn{2}{|c|}{$\begin{array}{l}\text { Secondary Childcare } \\
\text { Excluded }\end{array}$} & \multicolumn{2}{|c|}{$\begin{array}{c}\text { Secondary Childcare } \\
\text { Included }\end{array}$} & \multicolumn{2}{|c|}{$\begin{array}{l}\text { Secondary Childcare } \\
\text { Excluded }\end{array}$} & \multicolumn{2}{|c|}{$\begin{array}{l}\text { Secondary Childcare } \\
\text { Included }\end{array}$} \\
\hline & $\begin{array}{c}\text { OECD } \\
\text { Equivalence }\end{array}$ & $\begin{array}{c}\text { Sq. Root } \\
\text { Equivalence }\end{array}$ & $\begin{array}{c}\text { OECD } \\
\text { Equivalence }\end{array}$ & $\begin{array}{c}\text { Sq. Root } \\
\text { Equivalence }\end{array}$ & $\begin{array}{c}\text { OECD } \\
\text { Equivalence }\end{array}$ & $\begin{array}{c}\text { Sq. Root } \\
\text { Equivalence }\end{array}$ & $\begin{array}{c}\text { OECD } \\
\text { Equivalence }\end{array}$ & $\begin{array}{c}\text { Sq. Root } \\
\text { Equivalence }\end{array}$ \\
\hline \multicolumn{9}{|l|}{$90^{\text {th }}$ percentile/10 ${ }^{\text {th }}$ percentile } \\
\hline (1) Family income & $7.807^{\star \star}$ & $7.573^{\star \star}$ & $7.807^{\star \star}$ & $7.573^{\star \star}$ & $7.807^{* \star}$ & $7.573^{\star \star}$ & $7.807^{* \star}$ & $7.573^{\star \star}$ \\
\hline$(2)=(1)+$ Pred. $\mathrm{HH}$ production & 4.138 & 4.037 & 4.058 & $3.960 * \star$ & 4.058 & 3.960 & 3.555 & $3.743^{\star *}$ \\
\hline$(3)=(1)+$ Mean $\mathrm{HH}$ prod. & 4.174 & 4.055 & 4.027 & 3.916 & 4.027 & 3.916 & 3.570 & 3.446 \\
\hline$(4)=(2)+.25 \mathrm{~S}$ & 4.213 & 4.159 & 4.161 & $4.111^{* *}$ & $4.161^{*}$ & 4.111 & 3.580 & $3.796^{\star *}$ \\
\hline$(5)=(2)+.5 \mathrm{~S}$ & $4.307^{*}$ & 4.327 & 4.302 & $4.311^{\star *}$ & $4.302^{\star *}$ & $4.311^{\star \star}$ & $3.723^{\star \star}$ & $3.926^{\star *}$ \\
\hline$(6)=(2)+S$ & $4.631^{\star *}$ & 4.669 & $4.686^{\star \star}$ & $4.706^{\star \star}$ & $4.686^{\star \star}$ & $4.706^{\star \star}$ & $4.182^{\star \star}$ & $4.362^{\star \star}$ \\
\hline
\end{tabular}

Data are from the 2003 ATUS.

* Significantly different from Row (3) at 5 percent level.

** Significantly different from Row (3) at 1 percent level. 
Table 4: Coefficient of Variation For Differing Values of the Correlation of Household Production on Money Income and the Variance of Household Production

\begin{tabular}{|c|c|c|c|c|c|c|c|c|c|c|c|}
\hline & & \multicolumn{10}{|c|}{ Correlation } \\
\hline $\begin{array}{l}\text { Variance of Household } \\
\text { Production }\end{array}$ & & $\begin{array}{r}\text { Actual } \\
(-0.028)\end{array}$ & -1 & -0.5 & -0.2 & -0.1 & 0 & 0.1 & 0.2 & 0.5 & 1 \\
\hline (1) Money Income Only & $\mathrm{CV}$ & 0.917 & & & & & & & & & \\
\hline \multirow[t]{2}{*}{ (2) $\sigma_{P}=\sigma_{\widehat{P}}$} & $\mathrm{CV}$ & 0.655 & 0.524 & 0.595 & 0.634 & 0.646 & 0.658 & 0.670 & 0.682 & 0.716 & 0.770 \\
\hline & $\beta$ & -0.005 & -0.189 & -0.095 & -0.038 & -0.019 & 0.000 & 0.019 & 0.038 & 0.095 & 0.189 \\
\hline (3) $\sigma_{P}=0$ & $\mathrm{CV}$ & 0.647 & & & & & & & & & \\
\hline \multirow[t]{2}{*}{ (4) $\sigma_{P}=\sigma_{\widehat{P}}+.25 S$} & $\mathrm{CV}$ & 0.657 & 0.516 & 0.592 & 0.634 & 0.647 & 0.660 & 0.673 & 0.685 & 0.721 & 0.778 \\
\hline & $\beta$ & -0.006 & -0.202 & -0.101 & -0.040 & -0.020 & 0.000 & 0.020 & 0.040 & 0.101 & 0.202 \\
\hline \multirow[t]{2}{*}{ (5) $\sigma_{P}=\sigma_{\widehat{P}}+.5 S$} & $\mathrm{CV}$ & 0.663 & 0.494 & 0.586 & 0.634 & 0.650 & 0.665 & 0.680 & 0.694 & 0.736 & 0.800 \\
\hline & $\beta$ & -0.007 & -0.237 & -0.119 & -0.047 & -0.024 & 0.000 & 0.024 & 0.047 & 0.119 & 0.237 \\
\hline \multirow[t]{2}{*}{ (6) $\sigma_{P}=\sigma_{\widehat{P}}+S$} & CV & 0.688 & 0.425 & 0.569 & 0.641 & 0.663 & 0.684 & 0.705 & 0.725 & 0.782 & 0.869 \\
\hline & $\beta$ & -0.011 & -0.343 & -0.171 & -0.069 & -0.034 & 0.000 & 0.034 & 0.069 & 0.171 & 0.343 \\
\hline
\end{tabular}

Note: Household production measured using the square root equivalence scale, the specialist wage, and including secondary childcare. Data are from the 2003 ATUS. $\beta$ is the slope coefficient in a regression of household production on earnings. 